\title{
ДОСВІД І ПЕРСПЕКТИВИ НАВЧАННЯ СТУДЕНТІВ, ВДОСКОНАЛЕННЯ НАУКОВИХ ПОШУКІВ І ДОСЛІДЖЕНЬ НА КАФЕДРІ МЕДИЧНОЇ БІОХІМІЇ В СИСТЕМІ НОВІТНІХ ТЕХНОЛОГІЙ
}

\author{
М. М. Корда, Г. Г. Шершун, С. Р. Підручна, О. І. Острівка, Я. І. Гонський, \\ С. І. Яворська, А. Є. Мудра, Н. П. Саюк, Л. М. Рубіна, І. П. Кузьмак, М. І. Куліцька, \\ О. З. Яремчук, Н. Я. Матвіїв, Л. М. Палиця \\ ДВНЗ “Тернопільський держсавний медичний університет імені І. Я. Горбачевського МОЗ Украйни”

\section{EXPERIENCE AND PROSPECTS OF STUDENTS' STUDYING AND STUDIES OF IMPROVEMENT OF SCIENTIFIC RESEARCHES AT THE MEDICAL BIOCHEMISTRY DEPARTMENT IN THE SYSTEM OF NEW TECHNOLOGIES}

\author{
M. M. Korda, H. H. Shershun, S. R. Pidruchna, O. I. Ostrivka, Ya. I. Honskyi, \\ S. I. Yavorska, A. Ye. Mudra, N. P. Sayuk, L. M. Rubina, I. P. Kuzmak, M. I. Kulitska, \\ O. Z. Yaremchuk, N. Ya. Matviyiv, L. M. Palytsia \\ SHEI “Ternopil State Medical University by I. Ya. Horbachevsky of MPH of Ukraine”
}

\begin{abstract}
У статті відображено шляхи і перспективи вдосконалення методів навчання студентів через впровадження сучасних технологій, новітніх наукових досліджень. Акцентовано увагу на значенні біохімії як фундаментальної науки медицини.

In the article the ways and prospects of improvement of methods of students' studying by introducing of modern technologies and newest scientific researches are shown. Attention is accented on the value of biochemistry as fundamental science of medicine.
\end{abstract}

Вступ. Сучасний стан медицини вже не може повною мірою задовольнити наші потреби і вимагає напруженої роботи по ії реформуванню. І первинною ланкою цього процесу є підвищення якості підготовки кадрів у вищих навчальних закладах. Цей напрямок не може розвиватись і вдосконалюватись без застосування сучасних технологій навчання і водночас впровадження наукових досліджень у навчальний процес для формування у студентів професійних знань та умінь $[1,2]$. Наша робота є відображенням досягнень і перспектив удосконалення навчального процесу і наукових напрямків кафедри.

Основна частина. Теоретична основа клінічного мислення майбутнього лікаря започатковується при вивченні фундаментальних дисциплін, зокрема медичної біохіміі.

Слід зауважити, що біохімію неможливо механічно запам'ятати, можна лише зрозуміти логічну послідовність і взаємозв' язки всіх метаболічних процесів на різних рівнях цілісного організму, клітини, субклітинних, молекулярних структур. Одна справа запам'ятати певні біохімічні константи і зовсім інша
- вміти інтерпретувати конкретні випадки їх відхилень від норми у хворих, аналізувати діагностичні констеляції показників. 3 цієї точки зору біохімія відіграє провідну роль не тільки як базова основа клінічного мислення у встановленні діагнозу, але й розуміння обгрунтованого принципу застосування засобів лікування хворого.

Оскільки вивчення біохімії потребує логічного мислення, на кафедрі створена і активно використовується велика база клініко-біохімічних ситуаційних задач, розв' язання яких вимагає аналізу можливих варіантів логічного висновку. А самостійне визначення студентом кількох біохімічних показників на кожному занятті неодмінно спонукає до їх клінічного осмислення. Найкращим стимулом досягнення цієї мети є впровадження i успішне функціонування практично-орієнтованої системи (Z-системи) викладання біохіміі, на яку кафедра перейшла у 2006 році. Ця система передбачає одночасне вивчення теоретичних і практичних аспектів дисципліни, зміщення акцентів 3 теорії на практику. Навчання на практич-

\footnotetext{
(C) М. М. Корда, Г. Г. Шершун, С. Р. Підручна та ін.
} 
ному занятті сприяє поетапному накопиченню, засвоєнню і контролю знань. Саме етапність, послідовність і контроль - різні сторони процесу навчання, які дозволяють повніше засвоїти всі теми програми. При цьому найважливішим етапом є практична робота студентів - основний спосіб оволодіння навчальним матеріалом, робота під контролем викладача по оволодінню практичними навичками і отримання заліку у матрикулі. На матрикули винесені найважливіші біохімічні показники, які використовуються в діагностиці хвороб печінки, серця, нирок, підшлункової залози, сполучної тканини, цілої низки генетичних ферментопатій. На кафедрі медичної біохімії студенти повинні освоїти сучасні клінічні і лабораторні методи дослідження, навчитись аналізувати результати біохімічних аналізів крові, сечі, шлункового соку, слини. Наприклад, під час вивчення біохімії крові студент повинен вивчити також протеїнограму, ліпопротеїнограму, спектрограму крові, при вивченні біохімії нирок- параметри нормального аналізу сечі та можливі причини патологічних змін на біохімічному рівні, обміну вуглеводів - види цукрових кривих та методику цукрового навантаження.

Практично-орієнтована система (Z-модель) викладання передбачає одночасне вивчення теоретичних і практичних дисциплін, зі збільшенням частки клінічних предметів 3 кожним наступним роком навчання і зміщенням акцентів з теорії на практику, тобто недопустимим є проведення межі між теорією і практикою. “Z-система” є новітнім прогресивним методом підготовки студентів-медиків, яка сприяє засвоєнню основних та найсучасніших методів діагностики захворювань і принципів лікування хворих. Кредитно-модульна система організації навчального процесу наповнена великим позитивним потенціалом, яка відкриває студентам можливість інтегруватися до європейської та світової систем навчання, дає можливість бути конкурентоспроможними на світовому ринку праці, гідно представляти Україну, відкривати іiі для світового співтовариства [3-6].

3 переходом на циклову систему навчання, яка передбачає підвищення рівня викладання біохіміі, на кафедрі за кожним змістовним модулем (циклом) закріплені досвідчені викладачі та розподілено тематичні лабораторії. Конкретні викладачі протягом навчального року закріплені за певним циклом, вони глибоко вивчають усі сучасні методи дослідження зі свого циклу з використанням усіх інформаційних ресурсів. За такої організації навчального процесу викладач набуває вузької спеціалізації та досягає глибокого професіоналізму за напрямом вибраного циклу.
Кожна група студентів має можливість познайомитися із усіма викладачами кафедри. При захисті практичних робіт студент обов'язково повинен освоїти сучасні клінічні і лабораторні методи дослідження, навчитись пояснювати результати біохімічних аналізів крові, сечі, які отримані під час самостійної роботи, порівняти із нормою та припустити діагноз.

Під час вивчення біохімії передбачається поділ на 6 циклів, які відповідають типовим програмам навчання для медичного, стоматологічного та фармацевтичного факультетів. Цикл № 1 “Метаболізм вуглеводів та його регуляція" передбачає визначення глюкози глюкозоксидазним методом та методом цукрового навантаження, що надзвичайно інформативно при гіпер- та гіпоглікеміях, які зустрічаються при цукровому діабеті, пухлинах кори надниркових залоз та гіпофіза, гіперфункціях щитоподібної залози, голодуванні, передозуванні інсуліну, захворюванні нирок. Цикл № 2 “Метаболізм ліпідів та його регуляція” передбачає визначення ферментів травлення ліпідів, визначення жовчних кислот, фосфоліпідів, холестеролу, кетонових тіл, які служать діагностичним критерієм розладів ліпідного обміну (атеросклерозу 3 його ускладненнями, цукрового діабету, ендокринної патології тощо). Під час вивчення циклу № 3 "Метаболізм амінокислот, ензимопатії амінокислотного обміну” студенти визначають види кислотності шлункового соку, патологічні компоненти шлункового соку, що є важливим для діагностики і правильного вибору методу лікування захворювань шлунка i дванадцятипалої кишки, та активність трансаміназ в крові для діагностики захворювань печінки, серця. Цикл № 4 “Молекулярні механізми дії гормонів на клітини-мішені. Біохімія гормональної регуляції” передбачає якісне та кількісне визначення адреналіну в крові та сечі, вмісту в крові кальцію, фосфору, калію. Підвищення катехоламінів спостерігається при інсуліновій гіпоглікемії, гіпертиреозі, синдромі ЦценкаКушинга, а вміст мінеральних елементів є відображенням гормональної регуляції водно-мінерального обміну. Цикл № 5 “Біохімія харчування. Біохімія та патобіохімія крові” передбачає визначення вітамінів як незамінних нутрієнтів, вмісту загального білка плазми крові, білкових та ліпопротеїнових фракцій методом електрофорезу, залишкового азоту крові та білків у сечі. Цикл № 6 “Біохімічні функції печінки. Сечоутворювальна функція нирок” передбачає визначення білірубіну в крові, визначення креатиніну та загального азоту в сечі, продуктів детоксикації ендогенних сполук. Клініко-діагностичне значення вказаних показників є беззаперечним. 
3 впровадженням системи "MOODLE" викладачами нашої кафедри створено близько 300 тестових запитань, включаючи рисунки та ситуаційні задачі, до кожної теми, які постійно поновлюються і коригуються. Загальна база даних на сьогодні становить близько 6000 питань трьома мовами. Створено івпроваджено цілком нову екзаменаційну базу тестових завдань 3 використанням схем, графіків, таблиць, котрі увійшли в буклети для складання семестрового іспиту.

Також на кафедрі дистанційно навчаються студенти, які отримують ступінь медсестри-бакалавра. Навчання проводиться українською, російською та англійською мовами. Для цієї програми створено навчальну базу методичних розробок та тестових завдань, а також озвучено курс лекцій. Заняття 3 кожною групою проводяться за допомогою INTERNET зв'язку.

У зв'язку із інтенсивним розвитком медичної освіти настала потреба у написанні сучасного підручника для студентів, який би відповідав кредитно-модульній системі. Співробітники кафедри беруть участь у написанні національного підручника з біохімії для студентів-медиків. У перспективі планується видати “Лабораторний практикум з біохімії” українською та англійською мовами, де будуть представлені нові методики дослідження, а всі матеріали приведені у відповідності до навчання за "Z-системою". Для покращання щоденного контролю знань студентів необхідно поповнювати базу тестів, ситуаційних задач та графічних зображень.

Наука у вищій школі відіграє велику роль як стимул підвищення кваліфікації професорсько-викладацького складу, спосіб відтворення і розвитку інтелектуального потенціалу студентської молоді і служить потужним внеском у науково-технічний прогрес країни. Освітній процес у вищій школі повинен бути нерозривно пов'язаний з науковими пошуками.

Кафедра медичної біохімії працює сьогодні над виконанням науково-дослідної роботи, присвяченої вивченню механізмів впливу токсикантів різної природи на білково-ліпідний обмін та антиоксидантноімунний статус в експериментальних тварин та пошуку шляхів корекції виявлених порушень. Як токсиканти використовуються солі важких металів, фосфорорганічні сполуки, екстракт блідої поганки та інші антропогенні і біогенні ксенобіотики.

До наукової роботи постійно залучаються студенти. На кафедрі функціонує студентський науковий гурток, де молодь ознайомлюють 3 новими біохімічними методами дослідження. Проводять студентські симпозіуми, конференції з актуальних проблем сучасної медицини та біохімії. Гуртківці виступають 3 до- повідями на щорічних міжнародних конгресах молодих вчених, організованих в університеті, Україні та за кордоном.

Кафедра організувала проведення у 2009 та 2011 роках двох всеукраїнських науково-практичних конференцій: “Досягнення іперспективи експериментальної і клінічної біохіміі”" та “Біохімічні основи патогенезу ураження внутрішніх органів різної етіології та способи їх фармакологічної корекції”, які відбулися на базі конгрес-центру НОК “Червона калина”, і в яких брали участь делегати 3 наукових установ з усієї України, зокремаз Національного медичного університету імені О. О. Богомольця, Львівського національного університету імені Івана Франка, Харківського національного університету імені В. Н. Каразіна, Київського національного університету ім. Т. Шевченка, Вінницького, Донецького, Луганського, Запорізького, Львівського медичних університетів та ін.

За останні п'ять років науковцями кафедри опубліковано понад 100 наукових статей, в т. ч. і за кордоном, отримано ряд патентів на винаходи, зокрема "Спосіб моделювання цитотоксичної дії термічно ушкодженої біологічної тканини”, “Спосіб визначення рівня токсемії при політравмі”, “Спосіб моделювання процесу взаємодії токсинів блідої поганки 3 клітинами крові”, “Спосіб корекції антитоксичної функції печінки за умов гострого гепатиту" i інші.

У перспективах наукової роботи кафедри медичної біохімії: з'ясувати роль системи оксиду азоту у патогенезі ураження внутрішніх органів за дії антропогенних ібіогенних токсикантів різної природи; дати оцінку змінам інтенсивності перекисного окиснення ліпідів та окиснювальної модифікації білків за цих умов; з'ясувати особливості порушень системи антиоксидного та імунного захисту та їх роль у патогенезі викликаних уражень; встановити ступінь порушення енергозабезпечувального окиснення в мітохондріях внутрішніх органів за умов дії досліджуваних токсикантів; з'ясувати роль протеолітичної та калікреїнкінінової систем у патогенезі токсичного ураження.

В останні роки був розроблений широкий спектр наноматеріалів 3 унікальними властивостями для застосувань у різноманітних галузях - у промисловості, сільському господарстві, фармацевтичній i медичній галузях. Постійно зростаюча кількість даних свідчить про те, що завдяки спеціальним фізикохімічним властивостям, притаманним наноматеріалам, останні становлять загрозу для здоров'я людини. Тому значна увага приділяється виявленню потенційної токсичності наночастинок для клітин $і$ організмів. У перспективах наукової роботи кафедри 
планується всебічно дослідити вуглецеві наночастинки (фулерени $\mathrm{C}_{60}$, одно-і багатостінкові нанотрубки), які на сьогодні найширше використовуються, а також найпоширеніші наночастинки оксидів металів (заліза, цинку, міді, титану), в плані їх токсичного ефекту на біологічні системи. Буде вивчено характер i ступінь біохімічних змін, що відбуваються на молекулярному, клітинному, органному та організменому рівнях за різних способів (інгаляційно, перорально, транскутанно) введення наночастинок в організм.

В перспективі планується створити спільну з кафедрами фармакології та гігієни наукову біохімічну лабораторію та лабораторію клітинних культур, які будуть оснащені сучасним лабораторним обладнанням. Для цього вже придбаний сучасний спектрофотометр “Лямбда-25” відомої американської фірми Perkin Elmer, замовлено Імуноферментний аналіза-

\section{Лiтература}

1. Результати впровадження кредитно-модульної системи (ECTS) навчання на кафедрі медичної біохімії Тернопільського державного медичного університету / М. М. Корда, С. І. Яворська, Н. О. Суслова [та ін.] // Матеріали Всеукраїнської навчально-наукової конференції з міжнародною участю "Впровадження кредитно-модульної системи організації навчального процесу у ВМ(Ф)НЗ України : результати, проблеми та перспективи”, 20-21 травня 2010 р. - Тернопіль, 2010. - С. 58-59.

2. Досвід навчально-методичної роботи кафедри патологічної фізіології / Ю. С. Роговий, В. Ф. Мислицький, Л. О. Філіпова [та ін.] // Медична освіта. - 2001. - № 3. C. $38-40$.

3. Унгурян Л. М. Застосування тестової системи оцінки знань у навчальному процесі / Л. М. Унгурян, М. С. Образенко // Медична освіта. -2011. - № 3. - С. 20-22. тор STAT FAX 303, флюориметр флюорат - 0,2 -2M, хемілюмінометр "Lum-5773" та інше обладнання, яке дозволить на найсучаснішому рівні проводити біохімічні дослідження.

Висновки: 1. Набутий досвід показав, що впровадження практично-орієнтованої системи (Z-моделі) викладання біохімії сприяє формуванню у студентів клінічного мислення на основі аналізу біохімічних показників, отриманих при виконанні практичної роботи.

2. Циклова система навчання передбачає підвищення рівня викладання біохімії, викладачі набувають високої спеціалізації і глибокого професіоналізму за напрямком вибраного циклу.

3. Створення в перспективі міжкафедральної біохімічної лабораторії з сучасним оснащенням дозволить на високому рівні проводити наукові дослідження за обраним напрямком.

4. Досвід впровадження кредитно-модульної системи при викладанні фізіології / О. Г. Родинський, О. М. Демченко, О. В. Мозгунов [та ін.] // Медична освіта. - 2011. - № 3. -C. 125-128.

5. Результати впроваджень нових технологій навчання за кредитно-модульною системою у Вінницькому національному медичному університеті / В. М. Мороз, Т. Л. Полеся, Ю. Й. Гумінський [та ін.]//Медична освіта.-2011.-№2.-С. 83-85.

6. Впровадження Z-системи викладання практичних навичок на кафедрі фізіології / С. Н. Вадзюк, Н. М. Волкова, О. В. Денефіль [та ін.] // Матеріали Всеукраїнської навчально-наукової конференції з міжнародною участю "Впровадження кредитно-модульної системи організації навчального процесу у ВМ(Ф)НЗ України : результати, проблеми та перспективи", 20-21 травня 2010 р. - Тернопіль, 2010.C. 118-119. 